\title{
OS EXERCÍCIOS ESPIRITUAIS E A FORMAÇÃO DO JESUÍTA NO SÉCULO XVI
}

\author{
Wilson da Silva Prado ${ }^{1}$ \\ Paulo Romualdo Hernandes ${ }^{2}$
}

\begin{abstract}
Resumo
Este estudo analisa a obra Exercícios Espirituais, que corresponde ao primeiro instrumento para a formação do jesuíta, tanto por ter sido o primeiro formulado por Loyola, o fundador da Companhia de Jesus, e com o qual arregimentou os primeiros membros, como também por corresponder à fase inicial na formação do jesuíta, sem a qual ele não pode tornar-se membro da ordem religiosa. Os Exercícios Espirituais foram estudados nesta pesquisa em sua singularidade de obra pedagógica, embora nessa perspectiva não deixamos de considerar que o produto didático pertence a uma totalidade dentro de seu contexto histórico, tais quais as transformações da estrutura social da Europa do século XVI que determinaram a nova formação do homem desse período e que foram afetadas e afetaram o Novo Mundo. Os Exercícios Espirituais se inscrevem no movimento de mudanças necessárias para a nova ordem de produção da existência, que exige um homem menos contemplativo, mais ativo na defesa e na propagação da fé cristã, e, sobretudo, católica. No entanto, no Novo Mundo, na América portuguesa, mais especificamente, a prática de exercícios espirituais encontrou dificuldades em decorrência de seu ambiente selvagem, totalmente diferente daquele dos colonizadores.
\end{abstract}

Palavras-chave: Exercícios espirituais. Companhia de Jesus. Século XVI.

\section{THE SPIRITUAL EXERCISES AND THE JESUIT FORMATION IN THE XVI CENTURY}

\begin{abstract}
This study analyzes the Spiritual Exercises, which corresponds the Jesuit's first formation instrument, both because it was the first one formulated by Loyola, the founder of the Society of Jesus, and with which he recruited the first fighters, as also by corresponds to the initial phase in the formation of the Jesuit, without which he can not become a member of the Society of Jesus. Spiritual Exercises were studied in this research in its singularity of pedagogical work, although in this perspective we do not fail to consider that the didactic product belongs to a totality within its historical context, such as the transformations of the social structure of XVI century Europe that determined the new man's formation of that period and which were affected and affected the New World. The Spiritual Exercises are inscribed in the movement of changes necessary for the new order of production of existence, which requires a less contemplative man, more active in the defense and propagation of the Christian faith, and above all Catholic. However, in the New World, more specifically in
\end{abstract}


portuguese America, the practice of spiritual exercises encountered difficulties due to their wild environment, totally different from that of the colonizers.

Keywords: Spiritual exercises. Society of Jesus. XVI Century.

\title{
LOS EJERCICIOS ESPIRITUALES Y LA FORMACIÓN DEL JESUITA EN EL SÉCULO XVI
}

\begin{abstract}
Resumen
Este estudio analiza la obra Ejercicios Espirituales, que corresponde al primer instrumento para la formación del jesuita, tanto por haber sido el primero formulado por Loyola, el fundador de la Compañía de Jesús, y con el que arregimentó a los primeros miembros, como también por corresponder a la fase inicial en la formación del jesuita, sin la cual él no puede convertirse en miembro del orden religioso. Los Ejercicios Espirituales fueron estudiados en esta investigación en su singularidad de obra pedagógica, aunque en esa perspectiva no dejamos de considerar que el producto didáctico pertenece a una totalidad dentro de su contexto histórico, tales como las transformaciones de la estructura social de la Europa del siglo XVI que determinaron nueva formación del hombre de ese período y que fueron afectadas y afectaron el Nuevo Mundo. Los Ejercicios Espirituales se inscriben en el movimiento de cambios necesarios para el nuevo orden de producción de la existencia, que exige un hombre menos contemplativo, más activo en la defensa y la propagación de la fe cristiana, y sobre todo católica. Sin embargo, en el Nuevo Mundo, en la América portuguesa, más específicamente, la práctica de ejercicios espirituales encontró dificultades debido a su ambiente natural, completamente diferente de la de los colonizadores.
\end{abstract}

Palabras claves: Ejercicios Espirituales. Compañía de Jesús. Siglo XVI.

\section{CONSIDERAÇÕES INICIAIS}

Este estudo, que faz parte de pesquisa mais ampla e que tem como tema os jesuítas, a educação e a cultura brasileira, procurou trazer para o debate esse primeiro instrumento de formação do jesuíta, os Exercícios Espirituais. Obra importante na formação dos discípulos de Loyola para a militância pela Igreja Católica, mas também como obra pedagógica para trabalho junto aos fieis. Estudar os jesuítas e sua função de educadores é importante, pois esses agentes históricos estão na raiz da formação cultural brasileira e foram essenciais para a sua constituição e, portanto, alimentam o presente. (SAVIANI, 2008). Há que se estudar os jesuítas, também, pois novos documentos e, no caso deste estudo, novas análises de documentos, revelam muito sobre a formação do homem e da cultura brasileira que foram cristalizados por certa “[...] matriz de uma determinada história da educação brasileira [...]" 
(BITTAR e FERREIRA, 2007, p. 109) e que pode, por vezes, parecer que nada mais há para ser estudado.

A Companhia de Jesus foi fundada no século XVI no mesmo período em que a Reforma Protestante e a Reforma da Igreja Católica, também nomeada de Contrarreforma, se instituíram na Europa e provocaram mudanças nos modos de ação dos religiosos junto aos fieis. Essas transformações foram afetadas e afetaram o trabalho que era realizado com os habitantes do Novo Mundo. Segundo O’Malley (2004, p. 16), a história dos jesuítas é "[...] inseparável da então chamada contrarreforma, e eles têm sido frequentemente considerados símbolos de tudo o que era ruim ou de tudo o que era bom naquele acontecimento." A partir da perspectiva dialética da história, contudo, as ações dos jesuítas não devem ser consideradas a partir de juízos de valor como bondade ou maldade. Desse modo, o estudioso adepto de tal concepção de análise histórica deve conceber que esses religiosos fizeram parte de uma ordem da Igreja Católica recém-fundada com o objetivo de militar espiritualmente pela manutenção do poder dessa Igreja que se encontrava em crise por conta das mudanças estruturais da sociedade que determinavam transformações nas superestruturas, sobretudo na religião e na educação.

A Europa do século XVI encontrava-se em um momento de transição entre o ideário medieval para o moderno. O Humanismo Renascentista, que nesse período disputava fortemente o espaço com as ideias teológicas da Escolástica, encontrou em Erasmo de Roterdã um de seus principais expoentes. Crítico ao estilo escolástico, Erasmo considerava racional e fria a teologia desse período. Os humanistas buscavam a retórica, o convencimento "[...] que exigia engajamento da imaginação e de emoções tanto quanto do intelecto." (O’MALLEY, 2004, p. 395). Apesar das divergências dos primeiros jesuítas com o estudioso de Roterdã, O'Malley (2004) considera que esse ponto lhes era comum, citando, por exemplo, que, para Inácio de Loyola, o mais importante na teologia era essa busca por mover os afetos em direção ao serviço de Deus. Erasmo foi, segundo Skinner (1996), o mais importante humanista do Norte da Europa, sobretudo na Espanha, que foi lugar de nascimento e em que estudaram vários dos primeiros jesuítas, incluindo Inácio de Loyola. Teve também, segundo Bainton (1988), grande influência em Portugal, reino que impulsionou a criação da Companhia de Jesus e que enviou os jesuítas para as missões no Novo Mundo. (HERNANDES, 2010).

Para Manacorda (2006, p. 193), a civilização europeia do século XVI passava por uma "[...] expansão do espírito e dos conteúdos do humanismo [...] com a constituição dos modos de vida mais dinâmicos e mundanos." O homem do Humanismo europeu buscava uma espécie de libertação de suas energias, mesmo as religiosas, que, de forma paradoxal, haviam sido inibidas na Idade Média por uma cultura de total submissão à vida contemplativa, forjada pela Escolástica, ou mesmo por uma inibição de manifestação cultural livre, humanista. Segundo Berdiaev (1979, p. 118), no período medieval: 


\section{Revista HIIST'TEIDBR On-line}

ISSN: 1676-2584

Artigo

doi: $10.20396 /$ rho.v18i2.8652068

[...] no se otorgó al hombre la libertad de crear, de construir una cultura libre, de tal manera que al hombre no le fue dado experimentar y desplegar en la libertad las energías espirituales forjadas por el cristianismo y por el período medieval del hombre de la historia. La ascética medieval robusteció las energías del hombre, pero no dio ocasión a estas energías de desplegarse a través de la libre creación de una cultura.

Para Berdiaev (1979), portanto, esse descontentamento do homem com a centralização cultural do cristianismo se deu porque o medievo, ao disciplinar as energias espirituais humanas, as encadeou, mantendo-as subordinadas. Assim: "La experiencia de la historia moderna no es otra cosa que la experiencia de la libre manifestación de las energías humanas." (BERDIAEV, 1979, p. 118). Manifestação das energias humanas que conduziram, no século XVI, ao abalo do poder da Igreja Católica que mantinha essas energias sob seu controle.

Segundo Carvalho (2001), quando a Igreja Católica realizou certos atos, como a venda de indulgências, estes geraram revoltas nessa sociedade que estava se libertando em suas energias espirituais, o que provocou dissidências no interior da Igreja Católica. Erasmo e Lutero concordavam que não se coloca o céu a venda. (NASCIMENTO, 2006). Acontece a divisão na religião, especialmente na Alemanha, com Lutero, mas que em seguida alastrase com Calvino, em Genebra, e com Henrique VIII, na Inglaterra. A Igreja Católica reage com o Concílio de Trento (1545-1563). As discussões estendem-se às Universidades. Dentre as medidas do Concílio de Trento estão, por exemplo, a condenação das teses de Lutero como heréticas e a total proibição dos livros considerados heréticos, de autores como o próprio Lutero e Calvino. (MANACORDA, 2006). Além disso, os católicos reunidos em conselho reagiram contra os movimentos da Reforma que defendiam a livre interpretação da Bíblia, sem a necessidade de intermediadores.

No entanto, o Concílio de Trento marcou também mudanças na Igreja Católica no que diz respeito a sua atuação junto ao povo. Era necessário atuar mais nas ruas e menos nos conventos, nas abadias, nos claustros, nas Igrejas, em Roma. Diante de toda essa situação, somente as respostas teológicas, a racionalização e a frieza das ideias escolásticas não eram mais suficientes. Era o momento da prática, das ações e, diante desses desafios culturais, sociais e religiosos da Europa Renascentista é que se insere a Companhia de Jesus (STORCK, 2016), uma militância, um exército “[...] no permanente alerta da prevenção combativa." (CARVALHO, 2001, p. 283). É também nesse contexto do Humanismo que está inserido o fundador da Companhia de Jesus, Inácio de Loyola. (CARVALHO, 2001). Mas o humanismo jesuíta diferenciava-se do movimento humanista em geral, uma vez que buscava conciliar as novas ideias com a teologia escolástica, tendo em vista que não viam nos dois movimentos uma oposição propriamente dita. (O’MALLEY, 2004). Na prática, os jesuítas inseriam os ensinamentos escolásticos na retórica humanista, o que modificava a mensagem de forma considerável. 
O movimento jesuíta também está inserido no contexto da Devotio Moderna, que, por sua vez, relaciona-se às ideias de Gerard Groote (1340-1384) e ao modelo de vida divulgado pelos Irmãos da Vida Comum, que "[...] procuram adestrar-se, mediante aulas e exercícios místicos, para cultivar essa relação de autêntica submissão a Deus." (SKINNER, 1996, p. 304). Os Exercícios Espirituais formulados por Inácio de Loyola, pedagogia mística, tem esse caráter de conduzir o fiel à bandeira da Cruz, ou seja, de liberdade em alistar-se nessa bandeira, mas de total submissão à Vontade de Deus. Desde o século XIV, os Irmãos da Vida Comum se espalharam por toda a Europa, tendo como ideal a divulgação da religiosidade e da instrução. (STORCK, 2016). O movimento da Devotio Moderna também influenciou o principal adversário da Igreja Católica, Lutero, segundo Skinner (1996), sobretudo quando os discípulos de Gerard Groote, um de seus principais nomes, divulgadores da doutrina dessa nova forma de devoção, se amparam na:

Convicção central em seus ensinamentos, que pode ter derivado de alguns místicos de inícios do século XIV, como Mestre Eckhart (n. 1327) e seu discípulo Johannes Tauler (c. 1300-31), era que todos os esforços que os homens podem envidar a fim de se fazer querer por Deus nada expressam além de uma vaidade pecaminosa por isso, o fiel deve ter por meta apenas manter passiva a sua alma, simplesmente aceitando a graça divina. (SKINNER, 1996, p. 304).

A Devotio Moderna inspirou tanto protestantes como jesuítas, pois integrou as transformações da estrutura social europeia, que determinavam mudanças na superestrutura, com o crescente desenvolvimento de uma nova forma de produção da existência, alicerçada em uma nova classe que surge no terceiro estado e se fortalece e que nomeamos, atualmente, de burguesia. O povo leigo, sobretudo das cidades, o burguês, queria participar das práticas da igreja, retomar o cristianismo primitivo. Gerard Groote, por exemplo, era filho de burgueses. (LAUWERS, 2004). A religiosidade europeia caminhava, portanto, para uma popularização que esteve presente no início da Companhia de Jesus. Segundo O’Malley (2004, p. 411; 414, grifo do autor):

\begin{abstract}
O escolasticismo e o humanismo exerceram uma poderosa influência sobre os jesuítas, mas a literatura sobre a piedade medieval e do medievo tardio era, pelo menos, igualmente importante. Quanto a Inácio e os outros, a influência da Imitação de Cristo e de obras similares antedatou o escolasticismo e o humanismo e foi mais profunda [...] A Imitação clamava explícita e implicitamente por uma simplificação nas práticas da vida devota. Tais demandas eram um tema popular da época, encontradas também nos humanistas.
\end{abstract}

Havia, então, uma busca pela participação do leigo nas práticas religiosas, como a oração do rosário, as peregrinações aos lugares santos, os jubileus, o acender de velas em igrejas, o uso de relíquias dos santos, dentre inúmeras outras práticas de piedade popular e ascetismo religioso. (O'MALLEY, 2004). Essa possibilidade em viver a vida religiosa fora dos monastérios, dos conventos, para os leigos, pode ser verificada na mudança considerável de vida que teria ocorrido com o próprio mentor da Companhia de Jesus, Inácio de Loyola, 
quando de sua convalescência após a batalha de Pamplona: ao ler livros como a Vida de Cristo e a Legenda Áurea (populares à época), ao viver em Manresa, e ao realizar os exercícios espirituais formulados pelo Bispo García de Cisneros, tornou-se um peregrino e mais tarde um religioso fundador da Companhia de Jesus. Percebe-se, com isso, que ficara para trás o ideal religioso do monge medieval, do ermitão, e surgia um ideal novo, do leigo devoto, do missionário, do guerreiro da Igreja de Cristo. (HERNANDES, 2008).

Uma das ferramentas mais importantes para a piedade e ascetismo religioso que deixou os monastérios e conventos e foi levado para as ruas, para as cidades, pelos Irmãos de Vida Comum (FOUCAULT, 1977) foram exercícios místicos ou espirituais. Manuais que conduziam o fiel a viver a vida de Cristo interiormente e o colocavam em alerta e em luta contra o mal. (BAINTON, 1988). Dentre os manuais, destacam-se Imitação da Vida de Cristo, atribuído ao Irmão de Vida Comum, Tomas de Kempis, o de Erasmo de Roterdã, Manual do Soldado Cristão, e L'Exercitatorio de la vida espiritual, formulado por Garcia de Cisneros, abade de Manresa, nos finais do século XV, que foi realizado por Inácio de Loyola e o inspirou na composição dos seus Exercícios Espirituais. (DEMOUSTIER, 1996). Este último, aprovado por Roma, em 1548, quando o Concílio de Trento reformava a Igreja Católica, tornou-se ferramenta das mais importantes para a devoção e também para a formação do verdadeiro cristão, institucionalizado, portanto, pela Igreja. Os Exercícios Espirituais constam como exigência de prática junto aos fiéis desde a primeira Fórmula da Companhia de Jesus, de 1540, aprovada pelo papa Paulo III. (CONSTITUIÇÕES, 1997).

Esse movimento de mudanças estruturais e superestruturais da vida na Europa enfrentou desafios no Novo Mundo, que se encontrava em outra forma de cultura. Na América portuguesa, por exemplo, a vida é selvagem e tribal. A estrutura social é muito distante daquela que determinou os processos de transformação na formação do homem europeu do século XVI e também daquela que vivia o homem leigo ávido por religiosidade. (FEBVRE, 1968).

\title{
LIBERDADE DA VONTADE HUMANA ESCRAVIZADA À VONTADE DIVINA
}

Conta Inácio de Loyola (1987, p. 58 e 66), em sua autobiografia:

\begin{abstract}
Depois que o peregrino entendeu ser vontade de Deus não continuar em Jerusalém, veio sempre pensando consigo que faria. Por fim se inclinava mais a estudar algum tempo para ajudar as almas [...] chegou a Alcalá em 1526, e aí estudou termos de Soto, física de Alberto e o Mestre das Sentenças.
\end{abstract}

Vê-se que o fundador da Companhia de Jesus ia se formando em ideias da Escolástica, mas também do humanismo de Erasmo que exerceu forte influência em Alcalá e Salamanca. (SKINNER, 1996). Segundo O’Malley (2004), era a então Universidade de 
Alcalá influenciada por aspectos do Humanismo da Renascença italiana e pelos escritos de Erasmo de Roterdã. Escreve O'Malley que a estada em Alcalá de: “[...] Inigo foi favorecida por Miguel de Eguía, editor do original latino do Manual do Soldado Cristão de Erasmo (1525) e de sua tradução ao castelhano (1526)." (O’MALLEY, 2004, p. 50, grifo do autor). Dessa forma, pode-se pensar também em uma influência humanista do fundador da Companhia de Jesus nesse período. Por esse tempo, Inácio já aplicava seus Exercícios Espirituais (LOYOLA, 1987), manual de formação para a vida devota cristã que foi concebido por ele ter realizado os exercícios espirituais em sua estada de transformação religiosa em Manresa. Esses exercícios que Loyola vivenciou foram formulados por García de Cisneros, obra da nova forma de devoção, a Devotio Moderna, inspirada nos Irmãos de Vida Comum e em suas obras que podem ser consideradas obras do humanismo cristão e que influenciou Erasmo. (LAUWERS, 2004; BAINTON, 1988).

Em relação ao período de Alcalá, O'Malley (2004) considera que Inácio de Loyola, deve ter conhecido o pensamento de Erasmo, pelo menos através do Manual do Soldado Cristão. Cita algumas interpretações da obra e vida do fundador da Companhia de Jesus, no sentido de que Inácio teria se voltado contra Erasmo a partir de então, em razão de que a obra não era piedosa, mas O'Malley discorda dessas interpretações por diversos motivos, como, por exemplo, o fato de que esse texto era compatível com a piedade inaciana, não a contrariando. Além disso, as proibições do uso dos livros de Erasmo nos Colégios da Companhia, nos anos de 1550, se deram mais em razão da má reputação do humanista nessa época, do que pelos seus escritos propriamente ditos. Loyola conta, ainda, em sua autobiografia (1987), que foi preso pelo Santo Ofício em Alcalá porque os exercícios espirituais que aplicava pareciam conter ideias erasmianas, acusação que ele não rebate.

Alguns conceitos desenvolvidos pelo humanismo de Erasmo parecem importantes para se compreender melhor o contexto e as ideias da época, inclusive a posterior e acirrada disputa acerca da questão da liberdade da vontade que se encontra presente, também, nos Exercícios Espirituais e na própria missão da Companhia de Jesus.

A obra escrita por Erasmo em 1503, intitulada de Manual do Soldado Cristão (Enchiridion Militis Christiani, no original), tornou-se extremamente popular na Europa, e que o "[...] iria fazer porta-voz da reforma liberal católica, o conselheiro de papas e o mentor da Europa." (BAINTON, 1988, p. 76). Erasmo ensina a um soldado cristão nessa obra, mas também aos estudantes, militantes, como ele, que as armas para a luta por Cristo devem ser a oração, mas não indolente, e, sobretudo, a virtude, não somente para servir de exemplo para os inimigos do cristianismo, mas também a toda a cristandade. (ARNAUT DE TOLEDO, 2004). Nessa obra vemos presente a ideia da Devotio Moderna, ou seja, de uma religião mais ligada à sensibilidade, às emoções, menos racional e escolástica, mais popular e que poderia ser lida e compreendida individualmente. A obra se assemelhava a tantas outras obras que circulavam na Europa desse período, formulada pelos Irmãos de Vida Comum, a exemplo da principal delas, Imitação da Vida de Cristo, e que "[...] contém uma 
moral prática e normas de agir segundo o ideário cristão.” (ARNAUT DE TOLEDO, 2004, p. 96).

O Enchiridion de Erasmo seguiu essa linha de normas de comportamento e de uma preparação do indivíduo para a luta conhecendo, principalmente, a si mesmo. Dessa forma, Erasmo anuncia a possibilidade de se compreender as coisas através da ação, ou seja, a vivência das realidades teológicas esclarece a racionalidade, tornando-a mais completa. Nesse sentido é que, logo no início dessa obra, desenvolve-se a ideia de que a vida não é simples contemplação, mas uma prática árdua e combativa, que ajusta-se aos estudiosos e aos soldados: "É um apelo decidido à ação na guerra cristã." (BAINTON, 1988, p. 78). Apelo que pressupõe livre vontade do homem para agir, mas em favor da vida cristã.

A vontade humana é livre por natureza. Porém, o mesmo não acontece com a sua concretização. Nesta, a vontade só será livre se submetida à vontade divina. A liberdade, então, se dará por uma espécie de escravidão. O guerreiro cristão deve lutar continuamente contra os inimigos de Cristo, que, no caso de Erasmo, não é o Diabo, mas o mundo e a carne, a que ele, homem, pode sujeitar-se, pois tem livre vontade e pode escravizar-se, se não lutar todos os dias, submetendo sua vontade, escravizando-a, a Deus. Deve lutar cotidianamente com a certeza que irá vencer essa luta, diferente de um mercador que não sabe se terá sucesso no seu empreendimento, porque Deus é aliado na luta do militante cristão que submeteu sua vontade a Ele. (BAINTON, 1988).

O tema da vontade humana livre será aprofundado por Erasmo somente mais tarde, especificamente no ano de 1524, agora a partir de outro contexto: refutar as perigosas ideias luteranas cuja propagação já se iniciava na Europa. Na verdade, de início, tanto Erasmo quanto Lutero estavam de acordo em uma questão: criticar a Igreja Oficial de Roma pela corrupção que nela se estabelecera. (NASCIMENTO, 2006). Porém, Erasmo não aceita romper com a tradição de Roma, especialmente com a filosofia dos chamados Padres da Igreja. Segundo Skinner (1996), Erasmo escreve um tratado, em 1524, intitulado Sobre a liberdade da vontade, a pedido do papa, de Henrique VIII, dentre outros, a fim de refutar as teses de Lutero. Nesse tratado, Erasmo defende que:

\footnotetext{
O livre arbítrio é a vontade racional que, por ser racional, participa da dignidade da imagem que o homem possui de Deus [...] Erasmo considera a razão como o piloto da alma, assim como para o platonismo. A vontade localizada na alma, quando decide em favor do mundo material, se constitui como vontade má. A vontade racional é livre e, sendo assim, realiza seu movimento originário em direção ao mundo superior e divino. (NASCIMENTO, 2006, p. 96).
}

Dessa forma, o humanismo de Erasmo retoma a ideia de liberdade que se dá pela escravidão, ou seja, o homem é verdadeiramente livre porque pode decidir racionalmente como “[...] Deus quer que ele aja." (SKINNER, 1996, p. 286). Essa liberdade acontece por meio de sua submissão em favor do que ele chama de mundo superior. 


\title{
Revista HIISTESIDBR On-lime
}

Lutero irá discordar radicalmente de Erasmo. Segundo Skinner (1996, p. 286, grifo do autor):

Ele prontamente escreveu uma réplica elaborada e de excepcional violência [...] apresentando, de modo definitivo, sua doutrina anti-humanista e ultra-agostiniana do homem. Essa obra sai publicada em 1525, com o título de A servidão da vontade.

Nesta obra Lutero ataca a tese de Erasmo segundo a qual o homem tem poderes racionais para descobrir o que Deus quer que ele faça. Para Lutero, segundo Skinner (1996, p. 287), “[...] toda a capacidade racional do homem é carnal e absurda." Compreender o pensamento de Lutero sobre a vontade humana (pensamento esse que trará grandes consequências para a modernidade, por meio do movimento da Reforma) é compreender sua ideia sobre a natureza humana. Para Lutero, o homem não tem capacidade de descobrir a vontade de Deus porque a razão humana não pode conter a razão divina, por lhe ser inferior:

\begin{abstract}
A verdadeira situação, como Lutero parece indicar no título de seu tratado, é que nossas vontades permanecem sempre escravizadas ao pecado [...] Uma tal concepção às teses tomistas e humanísticas, que entendiam Deus como legislador racional, assume assim a forma de doutrina - tipicamente luterana - da dupla natureza de Deus. Há o Deus que escolheu revelar-se no Verbo [...] Mas há também o Deus escondido [...] A vontade do Deus absconso é onipotente; ela ordena tudo o que acontece no mundo. Mas também está além do nosso entendimento [...]. (SKINNER, 1996, p. 287-288).
\end{abstract}

A razão luterana sobre a impossibilidade racional de ação do homem no mundo, como modo de atender a Vontade de Deus, se impõe contra as ideias do humanismo de Erasmo, e, sobretudo, às ideias dos Exercícios Espirituais e da própria militância da Companhia de Jesus.

\section{EXERCÍCIOS ESPIRITUAIS E A FORMAÇÃO INICIAL DO JESUÍTA}

O início do movimento jesuíta do século XVI tem os Exercícios Espirituais como sua obra fundadora. Segundo Carvalho:

\footnotetext{
Inácio de Loyola, duro e pertinaz, conseguira entretanto alcançar a correta definição de si próprio, reduzindo a escrito os preceitos da sua orientação religiosa. Intitulou a obra de Exercícios espirituais para se vencer o homem a si mesmo e ordenar a sua vida sem determinar-se por afeição nenhuma desordenada, conjunto de regras extremamente severas, de contemplações, meditações e orações, conducentes à salvação da alma. (CARVALHO, 2001, p. 284).
}

Os Exercícios Espirituais foram desenvolvidos por Loyola quando, de sua transformação de militar para peregrino, resolve ir para Jerusalém a fim de tomá-la das mãos dos turcos. Durante sua peregrinação e o tempo em que passou em Jerusalém percebe que a luta não era mais para tomar a cidade santa dos infiéis mulçumanos, mas espiritual, ou seja, de formação espiritual dos cristãos por meio de exercícios que os fizessem viver 
interiormente a vida de Cristo. (HERNANDES, 2008). Além de um manual que leva o fiel à imitação da vida de Cristo, forma de devoção que circulava pela Europa, os exercícios de Loyola constituíram uma obra pedagógica, pois formavam o fiel como verdadeiro cristão, ou seja, que consegue discernir racionalmente, interiormente, sobre a Vontade de Deus para melhor servi-Lo. Nesse caso a influência de Erasmo se faz presente.

Os exercícios espirituais desenvolvidos por Loyola foram aplicados por ele antes mesmo de se tornar membro da Igreja Católica, como relata em sua autobiografia:

Em Alcalá exercitava-se em dar Exercícios Espirituais e declarar a doutrina cristã. Com isto fazia fruto para a glória de Deus. Muitas pessoas subiram da alta notícia e gosto de coisas espirituais. Outras sofriam várias tentações, como uma que querendo se disciplinar, não o podia fazer, como se lhe detivessem a mão. Estes e outros fatos causavam rumores no povo, principalmente pelo muito concurso de gente que havia onde quer que ele estivesse explicando a doutrina... (LOYOLA, 1987 , p. 66).

Embora a autobiografia de Loyola seja uma obra pedagógica, para formação dos discípulos da Companhia de Jesus, tendo como exemplo a vida de seu fundador e santo, ela não deixa de revelar e confirmar a popularização da religião, tanto no que diz respeito Inácio de Loyola, que, nesse momento em que aplicava os exercícios e não era membro da Igreja, quanto pelas muitas pessoas que o procuravam para se exercitar espiritualmente. É interessante observar também, a disciplina para leigos, ação de penitência saída dos monastérios e que era uma das ações que fazia parte da primeira semana de exercícios, o da purgação dos pecados. Os Exercícios Espirituais foram fundamentais para arregimentar os companheiros que fundariam, com Loyola, a Companhia de Jesus. Favre, um dos mais importantes fundadores da Companhia de Jesus praticará os Exercícios Espirituais em 1534, e com ele conhecemos o que significavam os Exercícios como obra de formação espiritual dos jesuítas desse período:

\begin{abstract}
A experiência dos Exercícios realizados por Favre sob a direção de Loyola, como ninguém ainda provavelmente pôde faze-los, numa entrega, num abandono total, merece nossa atenção por um instante: é como se ele atirasse uma tocha de fervor devorador sobre o currículo universitário clássico que acaba de concluir. Em fevereiro de 1534, o licenciado saboiano tranca-se num casebre isolado do bairro de Saint-Jacques, ao lado da atual Val-de-Grâce. O inverno é terrível: as carroças atravessam o Sena gelado. Pierre usa como cama a lenha que lhe dão para se aquecer a fim de avivar seu sofrimento. Fica oito dias sem se alimentar, recusando os goles de vinho que lhe oferece Ignácio, e chega a passar várias noites ajoelhado na neve. É preciso que Loyola - o ermitão irsuto de Manresa - assustado, o obrigue a pôr fim a essa insensatez. (LACOUTURE, 1994, p. 70, grifo do autor).
\end{abstract}

Pierre Favre, que era reconhecido estudioso de Aristóteles, no colégio de Santa Bárbara (LACOUTURE, 1994), ao fazer os exercícios une escolástica a essa nova forma de devoção, do humanismo, que seria a tônica de formação dos membros da Companhia de Jesus. Segundo O’Malley (2004), em 1548, já vigoravam os Exercícios Espirituais, com 


\title{
Revista HIISTEYIDIR On-line
}

Artigo

doi: $10.20396 /$ rho.v18i2.8652068

aprovação papal, documento este fundamental da nova ordem religiosa. Eram obrigatórios para todos os ingressantes na Ordem. Seu objetivo era conduzir o praticante a um momento central, a eleição, sendo que essa eleição deveria ser pela bandeira de Cristo na luta contra os infiéis aliados da bandeira de Lúcifer. Os Exercícios seriam, então, um livro dogmático, cuja mensagem cristã não está aberta ao debate, mas se pressupõe. A eficácia dos Exercícios parece residir em certa mensagem Humanista presente nos mesmos: “[...] a apropriação pessoal, um apego de todo o coração à mensagem e, depois, uma tradução de tudo isso de todo o coração para a própria vida." (O’MALLEY, 2004, p. 71). Nesse sentido, os Exercícios serviriam como forma de plasmar o jesuíta, de induzir os praticantes a seguirem os caminhos de seu elaborador, Inácio de Loyola, abandonando a vida mundana e carnal - mesma mensagem do Manual do Soldado Cristão, de Erasmo (BAINTON, 1988) -, e lutando pela vida espiritual. (HERNANDES, 2008).

Os Exercícios Espirituais, segundo o próprio Loyola (1966, p. 13), seriam:

\begin{abstract}
Qualquer modo de examinar a consciência, de meditar, de contemplar, de orar vocal e mentalmente, e outras operações espirituais [...] Pois assim como passear, caminhar e correr são exercícios corporais, da mesma forma se dá o nome de Exercícios Espirituais a todo e qualquer modo de preparar e dispor a alma, para tirar de si todas as afeições desordenadas e, afastando-as, procurar e encontrar a vontade divina, na disposição da vida para a salvação da alma.
\end{abstract}

Essa definição do que sejam os Exercícios Espirituais na lavra do próprio Loyola, que os formulou, e que se transformou em obra pedagógica fundamental na formação do jesuíta, sem a qual ele não podia fazer parte da Companhia de Jesus, revela as disputas no campo da religião e da formação do homem do século XVI. De um lado Loyola, certamente apoiado no humanismo cristão de Erasmo, defendendo a possibilidade de o homem de livre vontade encontrar por si mesmo, interiormente, a vontade divina, para a salvação de sua alma e, por outro lado, Lutero e a passividade da alma diante da vontade divina.

Esse poder de decisão sobre o que o fiel deveria fazer para seguir a Vontade de Deus, para melhor servi-Lo, é visível na segunda semana de exercícios, momento em que o fiel deveria fazer a eleição. A segunda semana de exercícios, no entanto, que é a via iluminativa, somente poderia ser realizada após, na primeira semana, que é a via purgativa. O fiel na primeira semana deve purgar-se de todos os pecados.

$1^{\circ}$. Ponto: aplicar a memória ao primeiro pecado, que foi dos anjos, depois a inteligência raciocinando, procurando compreender e pensar nos meus pecados e por fim à vontade querendo recordar tudo isso, para mais me envergonhar. Os anjos (lúcifer, satanás) pelo pecado da soberba foram para o inferno e eu com meus muitos pecados? $2^{\circ}$. Ponto: Proceder do mesmo modo, mas agora com o pecado de nossos pais Adão e Eva, trazendo para a memória como comendo do fruto da árvore da ciência pecaram, refletir pormenorizado sobre isso e depois exercitar a vontade para recordar. $3^{\circ}$. Ponto: Trazer à memória o pecado contra o Criador, Cristo, a gravidade e malícia desse pecado refletir com a inteligência, como, por 


\section{Revista HIISTEYIDIR On-line}

pecar contra a divindade foi condenado com razão e terminar com a vontade (LOYOLA, 1966, p. 49).

Observe-se que a atuação principal na lembrança dos pecados - na reflexão sobre essas transgressões bíblicas, e, na vontade de recordar, de pensar sobre o assunto, para poder seguir a Vontade de Deus - é do exercitante, guiado, obviamente, pelo Diretor Espiritual. As imagens criadas por Loyola na escrita dos exercícios, para os pecados dos anjos, de Adão e Eva, ou do pecado da humanidade contra o Criador, são pobres, e isso teria, segundo Barthes (1979), a intenção de fazer com que o exercitante criasse as imagens interiormente fazendo uso das três potências da alma: memória, inteligência e vontade, afim de que o fiel elaborasse o seu próprio entendimento sobre os pecados que deveriam ser purgados, penitenciados, e não por meio da fala do outro, do diretor espiritual. Estas imagens são disparadas por tópicas, por lugares comuns, linguagem comum conhecida, portanto, de todo e qualquer exercitante, seja ele homem da nobreza ou do povo, religioso ou leigo. Ainda na primeira semana há um forte disparador de imagens partindo de tópicas, quando o exercitante deve imaginar com todos os sentidos interiores o lugar para onde vão a alma dos pecadores:

\footnotetext{
$1^{\circ}$. ponto: ver com os olhos da imaginação as grandes chamas e as almas com corpos incandescentes. $2^{\circ}$ ponto: aplicar o ouvido aos prantos, alaridos, gritos, blasfêmias contra Cristo Nosso Senhor e contra todos os seus santos. $3^{\circ}$. ponto Com olfato sentir a fumaça, enxofre, cloacas e podridão. $4^{\circ}$. ponto: provar com o paladar coisas amargas, tais como lágrimas, tristeza e o verme da consciência. $5^{\circ}$. ponto: tocar com o tato como as chamas atingem e abrasam as almas. Colóquio: Num colóquio com Cristo Nosso Senhor, trazer à memória as almas que estão no inferno: umas, porque não creram na sua vinda, outras porque embora acreditassem, não procederam conforme Seus mandamentos, dividindo-as em três grupos: antes de sua vinda, durante sua vida, e após sua vida. E, logo agradecerlhe por não haver me deixado cair em nenhum desses grupos, pondo fim a minha vida. (LOYOLA, 1966, p. 59).
}

As tópicas que são disparadas por um diretor espiritual, pois os exercícios deviam ser dirigidos por guias espirituais, têm como intenção conduzir o exercitante a pensar, a refletir, a preencher a sua mente, com aquilo que interessa, a ele, para salvar sua alma, segundo aquilo que entendiam os jesuítas ser o melhor para o fiel. Os Exercícios têm o objetivo didático de, por meio de tópicas e contando com a ativa participação do exercitante, ensinar a verdade sobre a verdadeira natureza humana: servir a Deus, servir a Igreja de Cristo, a Igreja Católica, para salvar sua alma. As tópicas são um apelo para a ação do exercitante.

Como foi dito anteriormente, o momento da maior decisão que deve ser tomada pelo fiel, contando com a ajuda do diretor espiritual, acontece na segunda semana, no quarto dia de exercícios, quando, em meio à Natividade de Jesus, o fiel deve fazer sua escolha entre duas bandeiras: aquela do mal, de Lúcifer, de todos os inimigos que incitam a obtenção de riquezas, honra e soberba, e aquela bandeira do bem, de Cristo, obviamente, da Igreja Católica: 


\section{Revista HIIST'TEIDBR On-line}

$1^{\circ}$. Ponto: imaginar o caudilho de todos os inimigos como se estivesse sentado numa grande cadeira de fogo e fumaça, naquele grande campo de Babilônia, em figura horrível e aterradora. $2^{\circ}$. Ponto: considerar como (Lúcifer) convoca diversos demônios e os espalha pelas diversas cidades não omitindo nenhuma província, lugar, estado de vida ou pessoa em particular. $3^{\circ}$. Ponto: Considerar o discurso que dirige aos demônios e como os incita a lançar redes e cadeias, que, primeiramente devem tentar com a cobiça de riquezas, para depois obterem honra e soberba e com esses três graus induz a todos os outros vícios.

Bem ao contrário deve-se imaginar Nosso Senhor: $1^{\circ}$ ponto Cristo se apresentando em um grande campo aquele de Jerusalém, em lugar humilde e belo e gracioso. $2^{\circ}$. Ponto: como o Senhor reúne santos, apóstolos, discípulos e os envia por todo o mundo a fim de espalhar a sua sagrada doutrina. $3^{\circ}$. Ponto: considerar o discurso de Cristo dirige a todos amigos enviados a tal jornada três graus: $1^{\circ}$. Menosprezo à riqueza; 2 opróbrio ou menosprezo em oposição à honra mundana; $3^{\circ}$. humildade em oposição à soberba. E a partir desses três graus leve a todas as outras virtudes. (LOYOLA, 1966, p. 93).

$\mathrm{Na}$ eleição, na escolha pela bandeira de Cristo está, como em Erasmo, no Enchiridion, a liberdade da vontade do fiel, do exercitante, em escolher a bandeira de Cristo ou de Lúcifer. Liberdade que deve ser escravizada para Deus, se o fiel quiser salvar sua alma. Tanto nos Exercícios Espirituais, quanto no humanismo de Erasmo, a liberdade escravizada a Cristo, à Igreja, pretende conduzir a vida do fiel, para longe dos perigos do mundo e da carne, das riquezas, das honras e da soberba. Há, segundo os Exercícios Espirituais, três tempos para se fazer a escolha:

$1^{\circ}$. tempo: aquele em que Deus Nosso Senhor move e atrai a vontade de tal maneira, que, sem duvidar nem poder duvidar, tal alma devota segue o que se lhe mostra. Assim o fizeram São Paulo e São Mateus, ao seguirem a Cristo Nosso Senhor. $2^{\circ}$. tempo: é aquele em que se adquire muita clareza e conhecimento, através da experiência de consolações e desolações, bem como da experiência do discernimento dos vários espíritos. $3^{\circ}$. tempo: é tranquilo, considera-se, primeiro, para que nasceu o homem, isto é para louvar a Deus e salvar a sua alma. Desejando isso, elege como meio de vida ou estado, dentro das normas da Igreja, para assim encontrar ajuda no serviço de seu Senhor e salvação de sua alma. Disse tempo tranquilo, ou seja: quando a alma não é agitada por vários espíritos e usa de suas potências naturais livre e tranquilamente. (LOYOLA, 1966, p. 111-113).

O primeiro tempo é aquele da mística barroca quando o céu desce na terra para interferir na vida dos homens (BENJAMIN, 1984), vivida por São Paulo, São Matheus e pelo próprio Inácio de Loyola, segundo conta em seu Diário Espiritual (1977). O segundo tempo é para aqueles que são atormentados pelos vários espíritos, bons e maus, e devem discernir por aquilo que é o melhor para a vontade divina. O terceiro tempo significa, segundo Géza Kövecses (apud LOYOLA, 1966, p. 91): "[...] subjetivamente, a adaptação do querer e do agir humanos à Vontade Divina." Neste terceiro tempo está a regra essencial da Companhia de Jesus, a obediência do querer e do agir à Vontade Divina, que conduz o jesuíta à obediência de cadáver, inicialmente ao Papa e depois a todas as hierarquias da Igreja e da própria ordem, ou seja, sê tudo a todos. 
Nessa escolha pela bandeira do bem, indicada por tópicas pelos Exercícios Espirituais, escolha que deveria ser realizada pelo fiel exercitante de sua livre vontade, está didaticamente instruída a missão que todos os postulantes à Companhia de Jesus deviam realizar. Ao escolher a bandeira de Cristo, sendo, portanto, seu discípulo, o exercitante deveria seguir a Jesus em todos os seus passos para sua glória. Inicialmente era preciso que representasse um rei temporal para unir-se a ele e conquistar toda a terra de infiéis. Depois imaginar Cristo no lugar desse rei chamando-o como a todos os cristãos para conquistar todo o mundo de infiéis. Para tal era preciso deixar para trás toda sensualidade e ir contra o amor carnal e mundano. (LOYOLA, 1966).

\section{OS EXERCÍCIOS ESPIRITUAIS E A AMÉRICA PORTUGUESA}

Qual a força desses mesmos exercícios em terras da América portuguesa? Segundo Leite (2000b, p. 15-16): “A abnegação interior é a força da Companhia de Jesus. Fundada nos Exercícios, a sua espiritualidade reveste carácter magnífico de unidade, precisão, largueza de vistas, flexibilidade e segurança.” Ainda segundo Leite (2004, p. 354), a primeira pessoa que se submeteu aos Exercícios Espirituais, na América portuguesa, foi Simão Gonçalves, um soldado, a que Nóbrega dá notícia em uma carta de 9 de agosto de 1549. Após a prática, o soldado ingressou na Companhia de Jesus. Outro que é citado a fazer de forma frutuosa os Exercícios teria sido Mem de Sá, sob a direção do Padre Manoel da Nóbrega, por oito dias, após os quais viveu vida exemplar (LEITE, 2000a). No entanto, a prática dos exercícios parece ter enfrentado dificuldades por aqui.

Na América portuguesa, as primeiras dificuldades foram os prazos para realizar os Exercícios. A morosidade nos estudos (em razão das atividades práticas destas terras) atrasava a realização dos Exercícios no momento adequado. Em relação ao local para se realizarem, deveriam ser lugares onde se tornasse possível o isolamento. Assim, havia nos Colégios daqui cubículos ou casas apropriadas dificultando a realização dos exercícios conforme eram realizados na Europa, em conjunto. Leite (2000a) cita que Nóbrega fez uma casinha em Piratininga para esse fim e que, ali, diversos irmãos tiveram seus dias de oração, que renovaram o fervor e que, no Colégio da Bahia, nos anos de 1574, da mesma forma se recolhiam em exercícios para muito proveito e consolação de todos.

As divergências entre a prática na América portuguesa e as ordenações da Casa Geral da Congregação, em Roma, deixam entrever as diferenças na aplicação dos Exercícios na América portuguesa daquele da Europa, sobretudo em razão das condições de vida neste país. Não se fazia os Exercícios de uma só vez, ou seja, as quatro semanas, como era prática na Europa. Em regra, gastavam-se oito dias:

O clima molestava um pouco os Exercitantes. Em 1598, o mês de Exercícios, no noviciado, não se fazia 'todo junto'. O Visitador Manuel de Lima, em 1610, propunha ao Padre Geral que, no Brasil, por causa do calor, em vez de oito ou dez 
dias, tivessem os Padres ' 4 ou até 5, que é o que parece factível'. A proposta aparece riscada, sinal de não ser aceita. (LEITE, 2004, p. 354).

A vivência dos Exercícios nessas terras parece ter sido tão penosa que se chegou até mesmo a ordenarem-se os Exercícios a alguns, como penitência às suas faltas, fato que foi reprimido pelo Padre Geral, nos anos de 1579, que escreveu dizendo que isso só faria desacreditar essa prática espiritual. (LEITE, 2004, p. 354).

Era finalidade dos Exercícios tornar o praticante forte nas diversas virtudes, como a mortificação e a castidade, essa última exigida nos votos religiosos. Como vimos anteriormente era intuito dos Exercícios Espirituais fazer com que os exercitantes, sobretudo os noviços e os padres, dirigissem sua vontade para atender a vontade divina e afastar-se do mundo e da carne. No entanto, não havia local mais árduo para esse combate do que as terras brasileiras. Os irmãos novos iam para as Aldeias e: “[...] na flor da idade, sem a virtude ainda robustecida por uma formação demorada, enredavam-se nas torturas do isolamento e da dispersão, sem clausura suficiente e com contatos quase inevitáveis [...]”. (LEITE, 2004, p. $351)$.

Citando uma carta de Nóbrega, Leite dá notícia de que, supostamente, alguns “[...] Padres e Irmãos pecavam com as negras [...]" (LEITE, 2004, p. 351), e que mesmo portugueses que viviam com os índios eram pedras de escândalo e um estorvo, em razão de seus costumes sexuais. Por fim, cita Anchieta que, tendo confessado uma índia, ouviu dela que teria pecado carnalmente com um padre. O padre Anchieta, porém, tendo examinado bem o caso, não lhe deu mais atenção, considerando que teria sido um sonho, uma invenção.

Diante das dificuldades na formação do jesuíta para trabalhar na América portuguesa, os Exercícios Espirituais tornaram-se ferramenta essencial para outras funções que não a da formação do jesuíta, de condução de sua vontade. O terceiro ano de provação, que os jesuítas tinham que fazer, para confirmar os votos de pobreza, castidade e caridade, na América portuguesa foi iniciado apenas a partir de 1597, e teria sido facilitado com a realização de Exercícios Espirituais, segundo exigência do padre geral da Companhia de Jesus, padre Cláudio Aquaviva. Conforme adverte Aquaviva, ao padre Pero Rodrigues, provincial jesuíta da América portuguesa, em 1597:

[...] advertimos a V. R. o que já a outras partes temos avisado, que não é intenção nossa que, com os Padres de virtude, que foram operários alguns anos e estão cansados, se observe o $3^{\circ}$ ano em seu rigor, como o hão de cumprir aqueles que nele entram ao fim de seus estudos ou pouco depois. Mas bastará dar, aos tais, dois ou três meses, para fazerem os Exercícios Espirituais e alguns ofícios de humildade para seu maior proveito e edificação. (LEITE, 2004, p. 351).

Durante o noviciado na Companhia de Jesus, o noviço deveria fazer dois anos de provação, o terceiro ano de provação era para aqueles que se tornaram Padres, que na América portuguesa, em decorrência das dificuldades, foi introduzido apenas em 1597. Dentre as dificuldades estava a impossibilidade de se viver na mendicância, em hospitais, 
em um país selvagem. As possibilidades em se fazer provações adaptadas para a vida nas selvas, como visitar aldeias ou ir visitar as fazendas em lugares distantes, também se mostraram infrutíferas, pois os padres recém-formados corriam perigos materiais e espirituais na visita às aldeias ou eram muito bem recebidos pelos colonos que viviam distantes. (LEITE, 2004). Então, para não ficar sem o terceiro ano de provação, estimulados pelo padre Geral da Companhia, utilizaram-se os Exercícios Espirituais como provação.

Em certos escritos, por exemplo, a carta de Luiz da Grã ao padre Inácio de Loyola, do ano de 1554, parece indicar que fazer os Exercícios Espirituais tinha ainda outra função que não a formação do jesuíta. Na América portuguesa desse período, teria se tornado uma forma de exame para aqueles indivíduos que queriam pertencer à Companhia de Jesus, sobretudo se eram bons línguas, ou seja, se falavam bem o tupi: "Pedro de Guoes, que se aqui recebió y hizo los Exercícios, y se determino para la Compañia [...] Sabe la lengua mui bien.” (LEITE, 1954, p. 138).

\section{CONSIDERAÇÕES FINAIS}

Os Exercícios Espirituais foram a arma Humanista da Companhia de Jesus, capaz de direcionar totalmente a livre vontade do exercitante, escravizando-a à vontade divina. Esses Exercícios teriam promovido certa liberdade humana por se estabelecerem como Livre Arbítrio, no sentido de Erasmo de Roterdã, de que a vontade humana, em uma ação quase angélica, decide-se contra o mundo material (platonicamente considerado mal por essência) e dirige-se ao mundo superior e divino. (NASCIMENTO, 2006).

Os Exercícios Espirituais se impõem contra a visão luterana, que vê na ação do homem obra desnecessária, que não produz nem pode produzir efeito, uma vez que, segundo Lutero, este não possui vontade alguma além daquela escravizada ao pecado, vontade esta determinada desde sempre pelo Deus escondido que o homem não pode compreender. (SKINNER, 1996). Nesse último sentido, o homem poderia apenas buscar práticas espirituais de forma a confirmar um destino predeterminado, mas nunca persuadir ou ser persuadido do que já existe em si mesmo.

A experiência da formação pedagógica do jesuíta missionário na América portuguesa, no século XVI, formado pelos adaptados Exercícios Espirituais, parece apontar para essa síntese dialética entre liberdade da vontade humana para escolher os caminhos a seguir em sua missão evangelizadora e liberdade escravizada à descoberta (interior) dos rumos que levem a melhor forma de atender a vontade divina. Essa síntese possibilitou, para evangelizar os nativos do Novo Mundo, a liberdade de produzir adaptações nos modos de realizar a missão incluindo as adaptações feitas na América portuguesa na prática e nos objetivos dos Exercícios Espirituais. 


\section{REFERÊNCIAS}

ARNAUT DE TOLEDO, C. A. Sobre o enchiridion militis christiani, de Erasmo de Roterdão. Acta Scientiarum. Human and Social Sciences, Maringá, v. 26, n. 1, p. 95-101, 2004.

BAINTON, R. H. Erasmo da cristandade. Lisboa: Fundação Calouste Gulbenkian, 1988.

BARTHES, R. Sade, Fourier, Loiola. Trad. Maria de Santa Cruz. Lisboa: Edições 70, 1979.

BENJAMIN, W. Origem do drama barroco alemão. Tradução, apresentação e notas: Sergio Paulo Rouanet. São Paulo: Brasiliense, 1984.

BERDIAEV, N. El sentido de la historia: experiencia de la filosofia del destino humano. Madrid: Encuentro, 1979.

BITTAR, M.; FERREIRA, A. A pesquisa em história da educação colonial. In: PAIVA, J. M.; BITTAR, M.; ASSUNÇÃO, P. (Org.). Educação, história e cultura no Brasil colonial. São Paulo: Arké, 2007.

CARVALHO, R. História do ensino em Portugal desde a fundação da nacionalidade, até o fim do regime de Salazar-Caetano. 3. ed. Lisboa: Fundação Calouse-Gulbenkian, 2001 .

CONSTITUIÇÕES da Companhia de Jesus e normas e regras. São Paulo: Loyola, 1997.

DEMOUSTIER, A. L'originalité des exercices spirituels. In: GIARD, L.; VAUCELLES, L. de. (Dir.). Les Jesuítes à L'âge baroque (1540-1640). Grenoble: Edition Jeróme Millon er les auteurs, 1996.

FEBVRE, L. Au coeur religieux du XVI siècle, 2. éd. Paris: Bibliothéque Générale de L'École Pratique des Hautes Études, 1968.

FOUCAULT, M. Vigiar e punir. Nascimento da prisão. Tradução: Lígia M. Pondé Vassallo. Petrópolis: Vozes, 1977.

HERNANDES, P. R. A Companhia de Jesus no século XVI e o Brasil. Revista HISTEDBR [online], Campinas, n. 40, 2010. Disponível em: <http://www.histedbr. fae.unicamp.br/revista/edicoes/40/index.html>. Acesso em: 06 nov. 2017.

HERNANDES, P. R. Os exercícios espirituais da Companhia de Jesus e a educação. Revista HISTEDBR [online], Campinas: n. 30, p. 292-312. jun. 2008. Disponível em: <http://www.histedbr.fae.unicamp.br/revista/edicoes30/art18_30.pdf>. Acesso em: 06 nov. 2017. 
LACOUTURE, J. Os jesuítas 1: os conquistadores. Tradução de Ana Maria Capovilla. Porto Alegre: L\&PM, 1994.

LAUWERS, M. Verbete devotio moderna. In: LACOSTE, J. Y. (Dir.). Dicionário crítico de teologia. Tradução: Paulo Meneses. São Paulo: Paulinas; Loyola, 2004.

LEITE, S. História da Companhia de Jesus no Brasil. São Paulo: Loyola, 2004. (Tomo II).

LEITE. S. História da Companhia de Jesus no Brasil: século XVI - a obra. Belo Horizonte; Rio de Janeiro: Itatiaia, 2000ª (Tomo II).

LEITE, S. História da Companhia de Jesus no Brasil: século XVI - o estabelecimento. Belo Horizonte; Rio de Janeiro: Itatiaia, 2000b. (Tomo I).

LEITE, S. S. J. Cartas dos primeiros jesuítas do Brasil - 1553-1558. São Paulo: Comissão do IV centenário da cidade de São Paulo, 1954. v. 2.

LOYOLA, I. Autobiografia de Inácio de Loyola. Tradução e notas de Pe. Armando Cardoso, S. J. 3. ed. São Paulo: Loyola, 1987.

LOYOLA, I. Diário espiritual de Loyola, Inácio. Tradução e notas Pe. Armando Cardoso, S. J. São Paulo: Loyola, 1977.

LOYOLA, I. Exercícios espirituais. Orientação da tradução e anotações de Pe. Géza Kövecses S. J. 3. ed. Porto Alegre, 1966.

MANACORDA, M. A. História da educação da Antiguidade aos nossos dias. Tradução: Gaetano Lo Monaco. 12. ed. São Paulo: Cortez, 2006.

NASCIMENTO, S. F. do. "Erasmo e Lutero: o livre arbítrio da vontade humana". Revista de Filosofia. Curitiba, v. 18, n. 23, p. 89-103, jul./dez. 2006.

O’MALLEY, J. Os primeiros jesuítas. Tradução: Domingos Armando Donida. São Leopoldo, RS: Ed. da UNISINOS; Bauru: Ed. da EDUSC, 2004.

SAVIANI, D. História das ideias pedagógicas no Brasil. 2. ed. Campinas, SP: Autores Associados, 2008. (Coleção Memória da Educação).

SKINNER, Q. Fundações do pensamento político moderno. Tradução: Renato Janine Ribeiro. São Paulo: Companhia das Letras, 1996.

STORCK, J. B. Do Modus parisiensis ao ratio studiorum: os Jesuítas e a educação humanista no início da Idade Moderna. História da Educação, Porto Alegre: UFRS, v. 20, n 48, p 139-158, jan./abr., 2016. 


\section{Revista HIISTWADIBR On-line}

Notas

${ }^{1}$ Wilson da Silva Prado é especialista em Docência do Ensino Superior pelo Centro Universitário de Itajubá e, atualmente, discente do Programa de Pós-Graduação em Educação (Mestrado) da Universidade Federal de Alfenas (UNIFAL-MG). Pesquisa na área de História e Filosofia da Educação, especialmente Educação Jesuítica.

2 Paulo Romualdo Hernandes é docente permanente do Mestrado Profissional em História Ibérica e do Mestrado em Educação da Universidade Federal de Alfenas (UNIFAL-MG). Doutor em Educação pela Universidade Estadual de Campinas (UNICAMP). Autor do Livro O Teatro de José de Anchieta - Arte e Pedagogia no Brasil Colônia, resultado da pesquisa de Mestrado. Pesquisa e publicação que contaram com o apoio da FAPESP.

Submetido em: 28/03/2018

Aprovado em: 05/06/2018

Publicado em: 22/06/2018 